Original article

https://doi.org/10.26565/2075-3810-2019-41-02

УДК 577.32

\title{
INTERACTION OF SUPERPARAMAGNETIC IRON OXIDE NANOPARTICLES WITH DNA AND BSA
}

\author{
A.A. Skuratovska, D.A. Pesina, E.G. Bereznyak, N.A. Gladkovskaya, \\ E.V. Dukhopelnykov \\ O.Ya. Usikov Institute for Radiophysics and Electronics of National Academy of Sciences of Ukraine, \\ 12 Ac. Proskura St., Kharkiv, 61085, Ukraine \\ e-mail: anastasiia.skuratovska@gmail.com \\ Submitted August 7, 2018 \\ Accepted December 3, 2018
}

Background: Superparamagnetic iron oxide nanoparticles (SPION) are widely used in various biomedical technologies, in particular, as carriers for drug delivery to the target. Since SPION-drug complexes are planned to be used in vivo, it is necessary to find out if competitive binding of nanoparticles with biologically important macromolecules (nucleic acids and proteins) is possible.

Objectives: To investigate the possibility of complexation of iron oxide nanoparticles with DNA and serum albumin.

Materials and methods: Bare and sodium citrate coated SPION with different surface charges, bovine serum albumin (BSA) and calf thymus DNA were used. The complexes of SPION and macromolecules were precipitated by an external magnetic field. The research was carried out by spectrophotometry in visible and ultraviolet ranges.

Results: To study SPION interactions with DNA and BSA, the spectra of supernatants of the binary systems were compared with the spectra of the corresponding control macromolecules solutions. In the DNA-SPION systems, a decrease in the DNA absorption is observed only for bare nanoparticles. Our estimation shows that the maximum possible concentration ratio of bound DNA to SPION is about $2.5 \times 10^{-4} \mathrm{~mol} / \mathrm{g}$. The addition of sodium citrate coated SPION to the DNA solution does not cause any spectral changes of the supernatant. The interaction of BSA with SPION, coated with sodium citrate, leads to a slight increase in supernatant absorption compared with the one of the control protein solution. It can be caused by the fact that the resulting complexes are not precipitated by a magnetic field. No difference between the spectrum of the supernatant of BSA-bare SPION system and the control protein solution was observed.

Conclusions: The obtained spectrophotometric results demonstrate the formation of complexes between DNA and bare iron oxide nanoparticles as well as between BSA and the nanoparticles, coated with sodium citrate. The maximum concentration ratio of bound DNA and bare SPION was obtained for the investigated system. It is necessary to take into account when SPION are used as carriers for drug delivery.

KEY WORDS: superparamagnetic iron oxide nanoparticles (SPION); DNA; serum albumin; sodium citrate; complexation; spectrophotometry.

\section{ВЗАЕМОДІЯ СУПЕРПАРАМАГНІТНИХ НАНОЧАСТОК ОКСИДУ ЗАЛІЗА 3 ДНК І БСА \\ А.А. Скуратовська, Д.О. Песіна, К.Г. Березняк, Н.О. Гладковська, С.В. Духопельников Інститут радіофізики та електроніки ім. О.Я. Усикова НАН Украӥни, вул. Ак. Проскури, 12, Харків, 61085, Україна}

Актуальність. Суперпарамагнітні наночастки оксиду заліза широко використовуються у різноманітних біомедичних технологіях, зокрема, як носії лікарських препаратів для їх доставки до мішені. Оскільки планується використовувати комплекси наночасток оксиду заліза 3 препаратами in vivo, необхідно 3'ясувати, чи можливе конкурентне зв'язування наночасток 3 біологічно важливими макромолекулами (нуклеїновими кислотами та білками).

Мета роботи. Дослідити можливість комплексоутворення наночасток оксиду заліза 3 ДНК і сироватковим альбуміном.

Матеріали та методи. Використовувались немодифіковані та покриті цитратом натрію наночастки оксиду заліза з різними поверхневими зарядами, бичачий сироватковий альбумін

(c) Skuratovska A.A., Pesina D.A., Bereznyak E.G., Gladkovskaya N.A., Dukhopelnykov E.V., 2019 
(БСА) і ДНК з тимусу теляти. Комплекси наночасток з макромолекулами було осаджено за допомогою зовнішнього магнітного поля. Дослідження проводились методом спектрофотометрії у видимій і ультрафіолетовій областях.

Результати. Щоб дослідити взаємодію наночасток оксиду заліза з БСА і ДНК, спектри надосадових рідин подвійних систем порівнювались зі спектрами відповідних контрольних розчинів макромолекул. У системі ДНК-наночастки зменшення поглинання ДНК у надосадовій рідині спостерігається лише для немодифікованих наночасток. За нашими розрахунками, максимально можливе співвідношення концентрації зв'язаної ДНК до концентрації наночасток складає приблизно $2.5 \times 10^{-4}$ моль/г. Взаємодія БСА 3 наночастками, покритими цитратом натрію, викликає невелике зростання поглинання надосадової рідини відносно поглинання контрольного розчину білка. Це може бути пов'язано з тим, що утворені комплекси не осаджуються під впливом магнітного поля. Спектри надосадової рідини суміші БСА 3 немодифікованими наночастками i контрольного розчину білка практично не відрізняються.

Висновки. Отримані результати свідчать про те, що комплекси утворюються між ДНК і немодифікованими наночастками, а також між БСА та наночастками, покритими цитратом натрію. Це необхідно брати до уваги при використанні наночасток оксиду заліза у якості носіїв лікарських препаратів.

КЛЮЧОВІ СЛОВА: суперпарамагнітні наночастинки оксиду заліза; ДНК; сироватковий альбумін; цитрат натрію; комплексоутворення; спектрофотометрія.

\section{ВЗАИМОДЕЙСТВИЕ СУПЕРПАРАМАГНИТНЫХ НАНОЧАСТИЦ ОКСИДА ЖЕЛЕЗА} С ДНК И БСА

А. А. Скуратовская, Д. А. Песина, Е. Г. Березняк, Н. А. Гладковская, Е. В. Духопельников Институт радиофизики и электроники им. А. Я. Усикова НАН Украины, ул. Ак. Проскуры, 12, Харьков, 61085, Украина

Актуальность. Суперпарамагнитные наночастицы оксида железа широко используются в различных биомедецинских технологиях, в частности, в качестве носителей лекарственных препаратов для их доставки к мишени. Поскольку планируется использовать комплексы наночастиц оксида железа с препаратами in vivo, необходимо выяснить, возможно ли существование конкурентного связывания наночастиц с биологически важными макромолекулами (нуклеиновыми кислотами и белками).

Цель работы. Исследовать возможность комплексообразования наночастиц оксида железа с ДНК и сывороточным альбумином.

Материалы и методы. Использовались немодифицированные и покрытые цитратом натрия наночастицы с различными поверхностными зарядами, бычий сывороточный альбумин (БСА) и ДНК тимуса теленка. Комплексы наночастиц с макромолекулами осаждались под действием внешнего магнитного поля. Исследования проводились методом спектрофотометрии в видимой и ультрафиолетовой областях.

Результаты. Чтобы исследовать взаимодействие наночастиц с ДНК и БСА, спектры надосадочных жидкостей двойных систем сравнивались со спектрами соответствующих контрольных растворов макромолекул. В системе ДНК-наночастицы уменьшение поглощения ДНК наблюдается только для немодифицированных наночастиц. Согласно нашим исследованиям максимально возможное соотношение концентрации связанной ДНК к концентрации наночастиц составляет около $2.5 \times 10^{-4}$ моль/г. Взаимодействие БСА с наночастицами, покрытыми цитратом натрия, приводит к небольшому увеличению поглощения надосадочной жидкости по сравнению с поглощением контрольного раствора белка. Это может быть связанно с тем, что образованные комплексы не осаждаются под действием внешнего магнитного поля. Спектр надосадочной жидкости смеси БСА с немодифицированными наночастицами практически не отличается от спектра контрольного раствора белка.

Выводы. Полученные результаты свидетельствуют о формировании комплексов ДНК с немодифицированными наночастицами, а также БСА с наночастицами, покрытыми цитратом натрия. Это необходимо учитывать при использовании магнитных наночастиц оксида железа в качестве носителей лекарственных препаратов.

КЛЮЧЕВЫЕ СЛОВА: суперпарамагнитные наночастицы оксида железа; ДНК; сывороточный альбумин; цитрат натрия; комплексообразование; спектрофотометрия.

Superparamagnetic iron oxide nanoparticles (SPION) are a promising material for biological, biomedical and biotechnological applications $[1,2]$ due to their unique physical 
and chemical properties such as large surface-to-volume ratio, chemical stability, biocompatibility, and low toxicity [3-7]. Another advantage of SPION is an easy modification of the surface to change their charge which makes it possible to get electrostatic complexes of SPION with different types of drugs. All these properties and the ability to be controlled by an external magnetic field make SPION extremely perspective in the drug delivery.

For many types of drugs with different clinical applications, DNA is a target molecule. In case of using nanoparticles as drug carriers, the therapeutic effect depends on the interactions in the ternary drug-SPION-DNA system. Thus, the investigation of binding in the binary SPION-DNA system can simplify the further study of competitive interactions that take place in the ternary system.

After the injection of drug-SPION mixture into the bloodstream, interactions with plasma proteins occur. Binding of the nanoparticles with proteins, along with various factors like SPION size, shape, surface charge, and solubility, is considered one of the key elements that affect their biodistribution [8]. As shown in the review [8], the interactions with plasma proteins modulate the immune system response of the body and affect the circulation time of nanoparticles in the blood. For example, opsonin proteins stimulate phagocytosis, and, therefore, reduce the circulation time of nanoparticles, while dysopsonins (including albumins) promote prolonged circulation time of the particles in the bloodstream, when binding to them.

The present study of the interaction between both bare and modified with sodium citrate SPION and biologically important macromolecules, DNA and bovine serum albumin (BSA), is a necessary step for further development of the biomedical application of the iron oxide nanoparticles.

\section{MATERIALS AND METHODS}

Nanoparticles of iron oxide $\left(\mathrm{Fe}_{3} \mathrm{O}_{4}\right)$ were synthesized by cryochemical method [9]. The diameter of the nanoparticles is about $11 \mathrm{~nm}$. Suspensions of SPION in water and water solution of sodium citrate (NaCit) with concentration $C_{N a C i t}=8 \times 10^{-4} \mathrm{M}$ were used. The surface charge of bare iron oxide nanoparticles in water is slightly positive [10]. The coating of SPION by NaCit leads to the negative charge of their surface [11]. The concentration of stock suspensions of nanoparticles was $0.4 \mathrm{mg} / \mathrm{ml}$.

Commercial calf thymus DNA ("Serva") and bovine serum albumin ("Sigma") were used without additional purification. The stock solutions of DNA were prepared in distilled water with addition of $\mathrm{NaCl}\left(C_{\mathrm{NaCl}}=0.02 \mathrm{M}\right)$ and in sodium citrate solution $\left(C_{\mathrm{NaCit}}=8 \times 10^{-4} \mathrm{M}\right)$. The stock solutions of BSA were prepared in distilled water and in sodium citrate solution $\left(C_{\mathrm{NaCit}}=8 \times 10^{-4} \mathrm{M}\right)$. The concentrations of the macromolecules were determined using the molar absorption coefficients $\varepsilon_{280}=4.4 \times 10^{4} \mathrm{M}^{-1} \mathrm{~cm}^{-1}$ for BSA [12] and $\varepsilon_{260}=6.4 \times 10^{3} \mathrm{M}^{-1} \mathrm{~cm}^{-1}$ for DNA [13].

The stock SPION suspensions were diluted by the appropriate solvents and dispersed by ultrasound at two modes applied successively and repeated twice: $22 \mathrm{kHz}$ for $0.5 \mathrm{~min}$ and $44 \mathrm{kHz}$ for $5 \mathrm{~min}$. Experimentally we have shown that it is the optimum mode for dispersing.

The stock solutions of macromolecules were then added to the SPION suspensions. Obtained mixtures were stirred for $30 \mathrm{~min}$.

To take into account the possible kinetics of nanoparticles binding to the macromolecules, the samples were kept for 5 days. Then the mixtures were stirred again and exposed to the magnetic field $(0.42 \mathrm{~T})$ for 1 hour for precipitation of iron oxide nanoparticles and their complexes with the macromolecules. 
The control samples were prepared by dilution of the stock macromolecules solutions and SPION suspensions by the appropriate solvents. The concentrations of SPION and macromolecules in the control samples were the same as in the investigated mixtures.

Absorption spectra of control samples and supernatants of the mixtures were obtained by spectrophotometer "Specord M40" (Germany) in ultraviolet and visible spectral ranges. Quartz cells (1 $\mathrm{cm}$ and $5 \mathrm{~cm}$ optical path length) were used for the measurements. The measurement error of optical density was 0.005 units. The precipitation degree of SPION and SPION-macromolecules complexes was controlled by the intensity of the absorption at $340 \mathrm{~nm}$ (maximum absorption of iron oxide). The supernatant absorption was compared with the absorption of the control samples of DNA and BSA. Concentrations of macromolecules in the supernatants were calculated from the spectra intensities at the macromolecules absorption maxima (260 $\mathrm{nm}$ for DNA and $280 \mathrm{~nm}$ for BSA). The error of the concentration calculation was about $10 \%$.

\section{RESULTS AND DISCUSSION}

Figures 1a, b show absorption spectra of the control DNA solutions and the supernatants of DNA-SPION suspensions. The supernatant does not contain iron oxide nanoparticles (absorption at $340 \mathrm{~nm} A_{340}=0$ ). The intensity of the supernatant spectrum is lower than the one of the control solution. It can be caused by the DNA binding to bare iron oxide nanoparticles and precipitation of the DNA-SPION complexes by the external magnetic field. Previously the possibility of electrostatic complexes formation between positively charged nanoparticles and DNA was shown in [14-16].

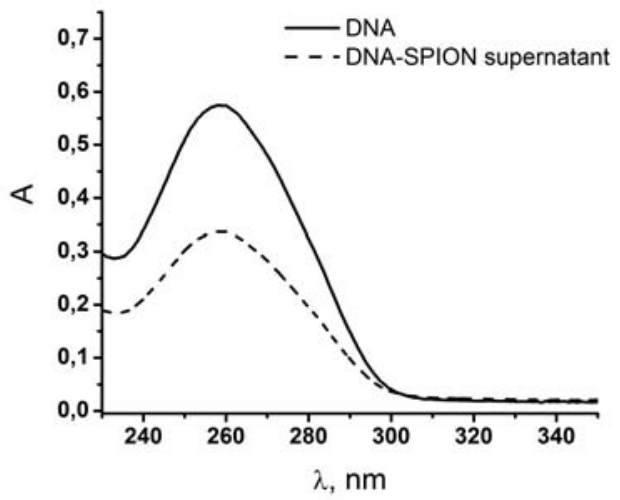

$\mathrm{a}$

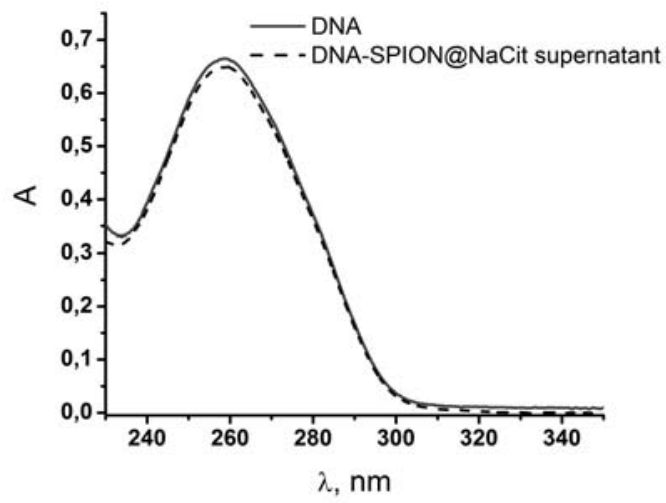

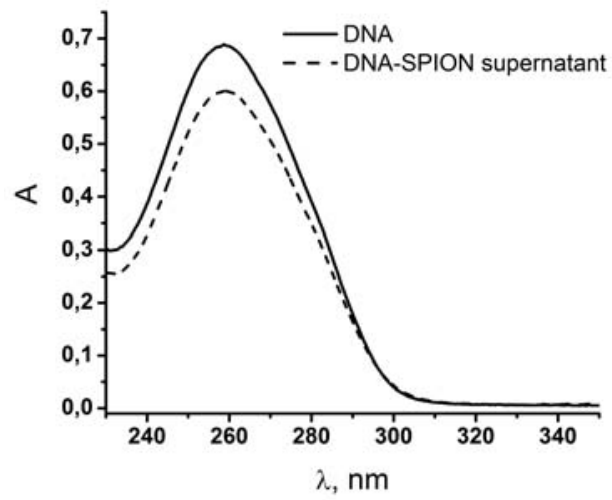

b

Fig. 1. Absorption spectra of DNA and supernatant of DNA-SPION suspension $(a, b)$.

Absorption spectra of DNA and supernatant of DNA-SPION@NaCit suspension (c).

The total DNA and SPION concentrations are

a) $C_{D N A}=0.15 \times 10^{-4} \mathrm{M}, C_{\text {SPION }}=0.06 \mathrm{mg} / \mathrm{ml}$;

b) $C_{D N A}=1.1 \times 10^{-4} \mathrm{M}, C_{S P I O N}=0.06 \mathrm{mg} / \mathrm{ml}$;

c) $C_{D N A}=1.1 \times 10^{-4} \mathrm{M}, C_{S P I O N}=0.06 \mathrm{mg} / \mathrm{ml}$. 
Table 1. The concentration of bound DNA and the concentration ratio of bound DNA and SPION in suspensions with different initial DNA concentration

\begin{tabular}{|c|c|c|c|}
\hline$C_{\text {SPION }}, \mathrm{mg} / \mathrm{ml}$ & $C_{D N A}, \mathrm{M}$ & $C_{\text {bound DNA }}, \mathrm{M}$ & $C_{\text {bound } D N A} / C_{\text {SPION }}, \mathrm{mol} / \mathrm{g}$ \\
\hline 0.06 & $0.15 \times 10^{-4}$ & $0.66 \times 10^{-5}$ & $1.1 \times 10^{-4}$ \\
\hline 0.06 & $1.1 \times 10^{-4}$ & $0.13 \times 10^{-4}$ & $2.2 \times 10^{-4}$ \\
\hline 0.06 & $2.2 \times 10^{-4}$ & $0.15 \times 10^{-4}$ & $2.5 \times 10^{-4}$ \\
\hline
\end{tabular}

The experiments at higher relative DNA concentrations demonstrate qualitatively similar results (Fig. 1b). However, amount of bound DNA changes. As can be seen from Table 1, with increase of the initial DNA concentration, the concentration of DNA bound to the nanoparticles rises up to $0.13 \times 10^{-4} \mathrm{M}$ and then practically does not change. The maximum possible ratio $C_{\text {bound } D N A} / C_{S P I O N}$ is about $2.5 \times 10^{-4} \mathrm{~mol} / \mathrm{g}$.

Absorption spectra of the control DNA solution and the supernatant of DNASPION@NaCit suspension practically do not differ (Fig. 1c). It indicates the absence of the DNA binding with the SPION@NaCit.

Though electrostatic interactions between DNA, a polyanion molecule, and negatively charged nanoparticles are impossible, negatively charged complexes of magnetic nanoparticles with certain drugs can bind to DNA in the minor groove [17]. Our studies indicate that for iron oxide nanoparticles coated with $\mathrm{NaCit}$ there is no mechanism of binding with DNA.

Fig. 2a shows absorption spectra of the control BSA solution and supernatant of the BSA-SPION@NaCit suspension. The supernatant spectrum intensity is greater than the one of the control solution. It should be noted that the higher absorption is also observed at the maximum of the iron oxide spectrum $(340 \mathrm{~nm})$.

The additional contribution to the absorption spectrum might be caused by the nanoparticles that did not precipitate under the influence of the magnetic field. To test this hypothesis, we compared the experimental spectrum of the system with superposition of the BSA spectrum and the spectrum of nanoparticles taken at the appropriate concentrations (Fig. 2a, dashed line). Since BSA does not absorb at $340 \mathrm{~nm}$, the concentration of unprecipitated nanoparticles was estimated by the supernatant absorption at this wavelength. It amounted to $7 \%$ of the initial SPION concentration. Total BSA concentration in the supernatant was the same as in the control solution.

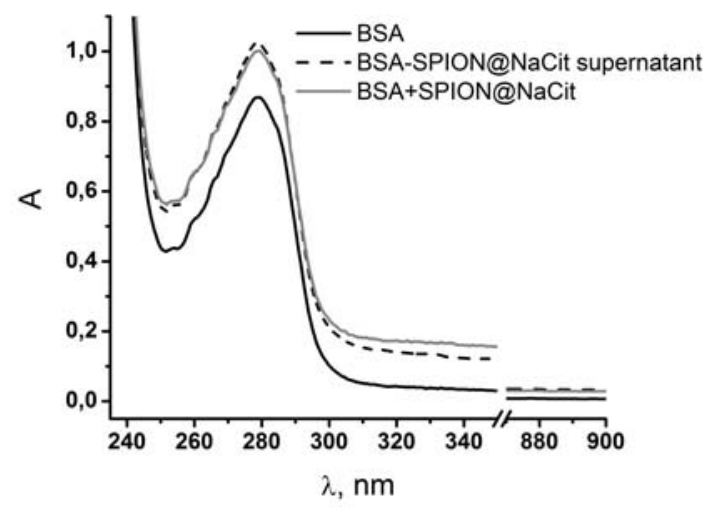

a

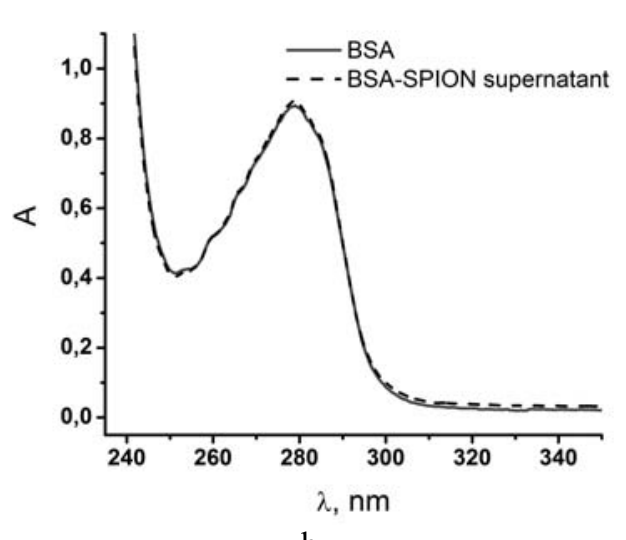

b

Fig. 2. Absorption spectra of BSA, the supernatant of BSA-SPION@NaCit suspension and the superposition of free BSA solution and SPION@NaCit suspension spectra (a). The total BSA and SPION concentrations corresponding to the experimental spectra are $C_{B S A}=2 \times 10^{-5} \mathrm{M}$ and $C_{S P I O N}=0.06 \mathrm{mg} / \mathrm{ml}$. The total BSA and unprecipitated SPION concentrations corresponding to the calculated superposition curve are $C_{B S A}=2 \times 10^{-5} \mathrm{M}$ and $C_{S P I O N}=0.0042 \mathrm{mg} / \mathrm{ml}$. Absorption spectra of BSA and the supernatant of BSA-SPION suspension (b).

The total BSA and SPION concentrations are $C_{B S A}=2 \times 10^{-5} \mathrm{M}$ and $C_{S P I O N}=0.06 \mathrm{mg} / \mathrm{ml}$. 
The experimental plot and the calculated superposition curve are in a good agreement. It confirms the presence of the SPION in the supernatant. Since under the same experimental conditions free nanoparticles precipitate completely, the observed effect should be due to the interaction of SPION with the protein.

Qualitatively similar changes take place with the increase of the total BSA concentration in the investigated suspensions up to $4.6 \times 10^{-5} \mathrm{M}$ (graphs are not shown). However, significant light scattering of both the control solution and the supernatant, which may be caused by the aggregation of the protein at the relatively high concentration, complicates the detailed data analysis.

The absorption spectrum of BSA does not change upon addition of bare iron oxide nanoparticles (Fig. 2b) which indicates that BSA does not interact with SPION.

\title{
CONCLUSIONS
}

Spectrophotometric studies of systems containing DNA and either bare or coated by sodium citrate SPION have shown the possibility of complexation between the positively charged SPION with DNA molecules. The maximum concentration ratio of bound DNA and bare SPION was obtained for the investigated system. It should be taken into account for application of SPION as carriers of the negatively charged drugs in the targeted delivery.

While bare SPION do not interact with BSA, minor interactions of negatively charged nanoparticles coated by sodium citrate with the protein are observed. It is shown that the formed BSA-SPION complexes can not be manipulated under the action of the external magnetic field.

\section{ACKNOWLEDGMENT}

The authors are grateful to Prof. A. G. Belous for providing the iron oxide nanoparticles samples. This work was supported, in part, by state order for research (0117U004039).

\section{CONFLICT OF INTEREST}

The authors declare that they have no conflict of interest.

\author{
Authors' ORCID ID \\ A.A. Skuratovska (Dhttps://orcid.org/0000-0001-6785-6952 \\ D.A. Pesina (Dhttps://orcid.org/0000-0001-7128-6841 \\ E.G. Bereznyak (iDhttps://orcid.org/0000-0003-1989-1408 \\ N.A. Gladkovskaya (Dhttps://orcid.org/0000-0002-5782-4567 \\ E.V. Dukhopelnykov iDhttps://orcid.org/0000-0001-7764-2181
}

\section{REFERENCES}

1. Pan, B.-F., Gao, F., \& Ao, L.-M. (2005) Investigation of interactions between dendrimer-coated magnetite nanoparticles and bovine serum albumin. Journal of Magnetism and Magnetic Materials, 293, 252-258. doi: 10.1016/j.jmmm.2005.02.018

2. Macaroff, P. P., Oliveira, D. M., Lacava, Z. G. M., Azevedo, R. B., Lima, E. C. D., Morais, P. C., \& Tedesco, A. C. (2004) The Effect of Bovine Serum Albumin on the Binding Constant and Stoichiometry of Biocompatible Magnetic Fluids. IEEE Transactions on Magnetics, 40(4), 3027-3029. doi: 10.1109/TMAG.2004.829204

3. Yang, Q., Liang, J., \& Han, H. (2009) Probing the Interaction of Magnetic Iron Oxide Nanoparticles with Bovine Serum Albumin by Spectroscopic Techniques. The Journal of Physical Chemistry B, 113(30), 10454-10458. doi: 10.1021/jp904004w

4. Xu, J.-K., Zhang, F.-F., Sun, J.-J., Sheng, J., Wang, F., \& Sun, M. (2014) Bio and Nanomaterials Based on $\mathrm{Fe}_{3} \mathrm{O}_{4}$. Molecules, 19, 21506-21528. doi: 10.3390/molecules191221506

5. Berry, C., \& Curtis, A. (2003) Functionalisation of magnetic nanoparticles for applications in biomedicine. Journal of Physics D: Applied Physics, 36, R198-R206. doi: 10.1016/j.nantod.2010.05.003 
6. Lu, A.-H., Salabas, E.L., \& Schuth, F. (2007) Magnetic nanoparticles: synthesis, protection, functionalization, and application. Angewandte Chemie-International Edition, 46, 1222-1244. doi:10.1002/anie.200602866

7. Kudr, J., Haddad, Y., Richtera, L., Adam, V., \& Zitka O. (2017) Magnetic Nanoparticles: From Design and Synthesis to Real World Applications. Nanomaterials, 7(9), 243. doi: 10.3390/nano7090243

8. Aggarwal, P., Hall, J. B., McLeland, Ch. B., Dobrovolskaia, M. A., \& McNeil S. E. (2009) Nanoparticle interaction with plasma proteins as it relates to particle biodistribution, biocompatibility and therapeutic efficacy. Advanced Drug Delivery Reviews, 61(6), 428-437. doi: 10.1016/j.addr.2009.03.009

9. Yelenich, O.V., Solopan, S.O., Kolodiazhnyi, T.V., Greneche, J.M., \& Belous A.G. (2015) Synthesis of iron oxide nanoparticles by different methods and study of their properties. Solid State Phenomena, 230, 108-113. doi: 10.4028/www.scientific.net/SSP.230.108

10. Vakula, A., Tarapov, S., Bereznyak, E., Gladkovskaya, N., Dukhopelnikov, E., \& Herus A. (2016) Spectral Investigation of Magnetite Nanoparticles Interaction with Charged Drugs. 9th international Kharkiv symposium on physics and engineering of microwaves, millimeter and submillimeter waves MSMW'2016, Kharkiv, June 21-24, 2016. (pp. A30). doi: 10.1109/MSMW.2016.7538006

11. Nigam, S., Barick, K.C., \& Bahadur, D. (2011) Development of citrate-stabilized $\mathrm{Fe}_{3} \mathrm{O}_{4}$ nanoparticles: conjugation and release of doxorubicin for therapeutic applications. Journal of Magnetism and Magnetic Materials, 323, 237-243. doi: 10.1016/j.jmmm.2010.09.009

12. Gill, S. C., \& von Hippel, P. H. (1989) Calculation of Protein Extinction Coefficients from Amino Acid Sequence Data. Analytical Biochemistry, 182(2), 319-326. doi: 10.1016/0003-2697(89)90602-7

13. Barcelo, F., Capo, D., \& Portugal, J. (2002) Thermodynamic characterization of the multivalent binding of chartreusin to DNA. Nucleic Acids Research, 30(20), 4567-4573. doi: 10.1093/nar/gkf558

14. Yiu, H. H. P., Bouffier, L., Boldrin, P., Long, J., Claridge, J. B., \& Rosseinsky, M. J. (2013) Comprehensive Study of DNA Binding on Iron(II,III) Oxide Nanoparticles with a Positively Charged Polyamine ThreeDimensional Coating. Langmuir, 29(36), 11354-11365. doi: 10.1021/la400848r

15. Haddad, Y., Xhaxhiu, K., Kopel, P., Hynek, D., Zitka, O., \& Adam, V. (2016) The Isolation of DNA by Polycharged Magnetic Particles: An Analysis of the Interaction by Zeta Potential and Particle Size. International Journal of Molecular Sciences, 17(4), 550. doi: 10.3390/ijms 17040550

16. Liu, C. H., Tsao, M. H., Sahoo, S. L., \& Wu, W. C. (2017) Magnetic nanoparticles with fluorescence and affinity for DNA sensing and nucleus staining. RSC Advances, 7, 5937-5947. doi: 10.1039/C6RA25610D

17. Shahabadi, N., Falsafi, M., Feizi, F., \& Khodarahmi, R. (2016) Functionalization of $\gamma-\mathrm{Fe}_{2} \mathrm{O}_{3} @ \mathrm{SiO}_{2}$ nanoparticles with antiviral drug zidovudine: Synthesis, characterization, in vitro cytotoxicity and DNA interaction studies. RSC Advances, 6, 73605-73616. doi: 10.1039/C6RA16564H 